\title{
Need of the Hour: Awareness on Green Banking Products
}

\author{
CATHERIN. T. C. ${ }^{1}$, C. L. JEBA MELVIN ${ }^{2}$ \\ ${ }^{1}$ Ph.D. Full Time Research Scholar, (Regd.19213111062055), Research Centre of Management Studies, \\ N.M. Christian College, Marthandam, Affiliated to Manonmaniam Sundaranar University, Abishekapatti, India. \\ E-mail:tccatherin@gmail.com, \\ ${ }^{2}$ Associate Professor \& Head of Research Centre, Department of Management Studies, N.M. Christian College, \\ Marthandam, Affiliated to Manonmaniam Sundaranar University, Abishekapatti, India. \\ E-mail: jebamelwyn@gmail.com
}

\begin{abstract}
Human beings for their self-centeredness, warmth, and leisure in their life, have chosen the avenue of globalization, technological advancement, and industrialization. The price that they are paying for this avenue is the catastrophe of biodiversity, climatic changes, global warming, depleting resources, melting of glaciers, and the catastrophe of greenery. Hence environmental sustainability and sustainable development have turned into a crucial agenda in the global association. India is a rapidly flourishing nation which is backed by the industrial sectors, yet it is exposed terribly to climatic change and global warming. Due to this alarming plight, the banking sectors who are the chief financial supporter of industries that cause pollution have taken a small start: Going Green. This has given push up to the conception of green banking and it has given birth to green banking products. The green banking products target cutback of carbon impression, resource-efficient economies, and ward off wastage of the accessible limited resources. It is focused upon moving towards banking practices that are non-hazardous to the environment and aids to conserve it. These green banking products initiatives have recently kick-started in a handful of banks across the country. Fueling of green products is required at a quick pace than anticipated, as they have a close association with other sectors that forms the country's economy. This paper skates through the Need of the Hour and the awareness on Green Banking Products
\end{abstract}

Keywords: Green Banking; Green Banking Products; Customer Awareness; Climate Change; Global Warming.

JEL Classification: C1, L2

Received: June 02, 2021

Accepted: September 13, 2021 


\title{
La Necesidad del Momento: Concienciación sobre los Productos Bancarios Ecológicos
}

\author{
CATHERIN. T. C. ${ }^{1}$, C. L. JEBA MELVIN ${ }^{2}$ \\ ${ }^{1}$ Ph.D. Full Time Research Scholar, (Regd.19213111062055), Research Centre of Management Studies, \\ N.M. Christian College, Marthandam, Affiliated to Manonmaniam Sundaranar University, Abishekapatti, India. \\ E-mail:tccatherin@gmail.com, \\ ${ }^{2}$ Associate Professor \& Head of Research Centre, Department of Management Studies, N.M. Christian College, \\ Marthandam, Affiliated to Manonmaniam Sundaranar University, Abishekapatti, India. \\ E-mail: jebamelwyn@gmail.com
}

\begin{abstract}
RESUMEN
Los sereshumanos, por suegocentrismo, calidez y ocioensuvida, hanelegido la vía de la globalización, elavancetecnológico y la industrialización. El precio que estánpagando por estavía es la catástrofe de la biodiversidad, los cambiosclimáticos, elcalentamiento global, elagotamiento de los recursos, eldeshielo de los glaciares y la catástrofe de la vegetación. De ahí que la sostenibilidadmedioambiental y eldesarrollosostenible se hayanconvertidoen una agenda crucial en la asociaciónmundial. India es una nación que florecerápidamente y que estárespaldada por los sectoresindustriales, peroestáterriblementeexpuesta al cambioclimático y al calentamiento global. Debido a estaalarmantesituación, los sectoresbancarios, que son el principal apoyofinanciero de las industrias que causancontaminación, han dado un pequeño paso: Going Green. Esto ha impulsado la concepción de la banca verde y ha dado lugar a productosbancariosverdes. Los productosbancariosverdestienencomoobjetivo la reducción de la impresión de carbono, las economíaseficientesencuanto a recursos y la prevención del despilfarro de los limitadosrecursosdisponibles. Se centra enavanzarhaciaprácticasbancarias que no seanpeligrosas para el medio ambiente y que ayuden a conservarlo. Estasiniciativas de productosbancariosverdes se hanpuestoenmarcharecientementeen un puñado de bancos de todoelpaís. El impulso de los productosverdes es necesario a un ritmomásrápido de lo previsto, ya que tienen una estrecharelación con otrossectores que forman la economía del país. Este artículoaborda la necesidad del momento y la concienciaciónsobre los productosbancariosverdes.
\end{abstract}

Palabras clave: Banca Verde; ProductosBancarios Verdes; Concienciación del Cliente; Cambio Climático; Calentamiento Global.

Clasificación JEL: C1, L2

Recibido: 02 de Junio de 2021

Aceptado: 13 de Septiembre de 2021 


\section{Introduction}

Human beings for living a rich and prosperous life they penance the sound environment to make their economy strong. They initiated globalization, industrialization, and technological development for making the economy tenacious for increasing the standard of living of the society (Deepa and Karpagam, 2018). But they fail to notice the economy, society and the environment are the interconnected mainstays of sustainability. For the advancement of economy and society, the cost that they paid is degradation of the environment, which brings out dangerous global warming, climate change, loss of biodiversity, depletion of natural resources, melting of glaciers, dissertation, tornado, pollution, and loss of greenery (Malliga and Revathy, 2016; Deepika, 2015). Presently the planet is in an alarming plight and life on earth is in live or dies condition. Henceforth environmental sustainability and sustainable development become a significant agenda in the world community. The pre-eminent polluting industries like paper and pulp, pesticides/insecticides, fertilizers, metallurgical industries, refines, textiles, tanneries, chemical/pharmaceuticals, sugar, and so on, are the major backbone of the economic growth of a nation. For these ventures, finance is the lifeblood that is subsidized by the backbone of the economy called the banking sector (Deka, 2018).

Banks are non-polluters and environmental friendly in terms of their internal activities, emanation, and pollution. But their external activity by their customers on the environment is gigantic and tough to estimate. The banking sector realized its corporate social responsibility and started considering ecological aspects in lending finance to its customers (Vijai, 2018). Furthermore, they also initiated to promote the products, process, and services which cutback the carbon impressions from the banking activities (Nasila, 2020). Society gets mindful about the need for sustainable development and safeguarding of the environment, so they demand all businesses to show their responsibility to safeguard the environment and society (Ganesan and Bhuvaneswari, 2016).While comparing with other sectors, the banking sector has the incredible responsibility to develop and maintain sustainability in their internal as well as external banking activities (Kumar, 2017). To reach the goal of sustainable development and environmental sustainability banks take a small stride: Going Green. The mantra 'Going Green' ascends to the revolutionary concept of Green Banking.

\section{Green banking products}

Green Banking is the concept, which aims to make the internal and external banking activities by banks and customers sustainable by diminishing the carbon impressions through making advancements in banking products and services, processes, channels, and technology. It elevates environmental friendly practices to safeguard the environment and to develop sustainability by balancing the environment, economic, and social the three mainstays of sustainability (Giridhar and Sudhakar, 2017). Ethical bank, sustainable bank, environmental friendly bank, socially responsible bank and eco friendly bank are the nicknames of Green Banking. 


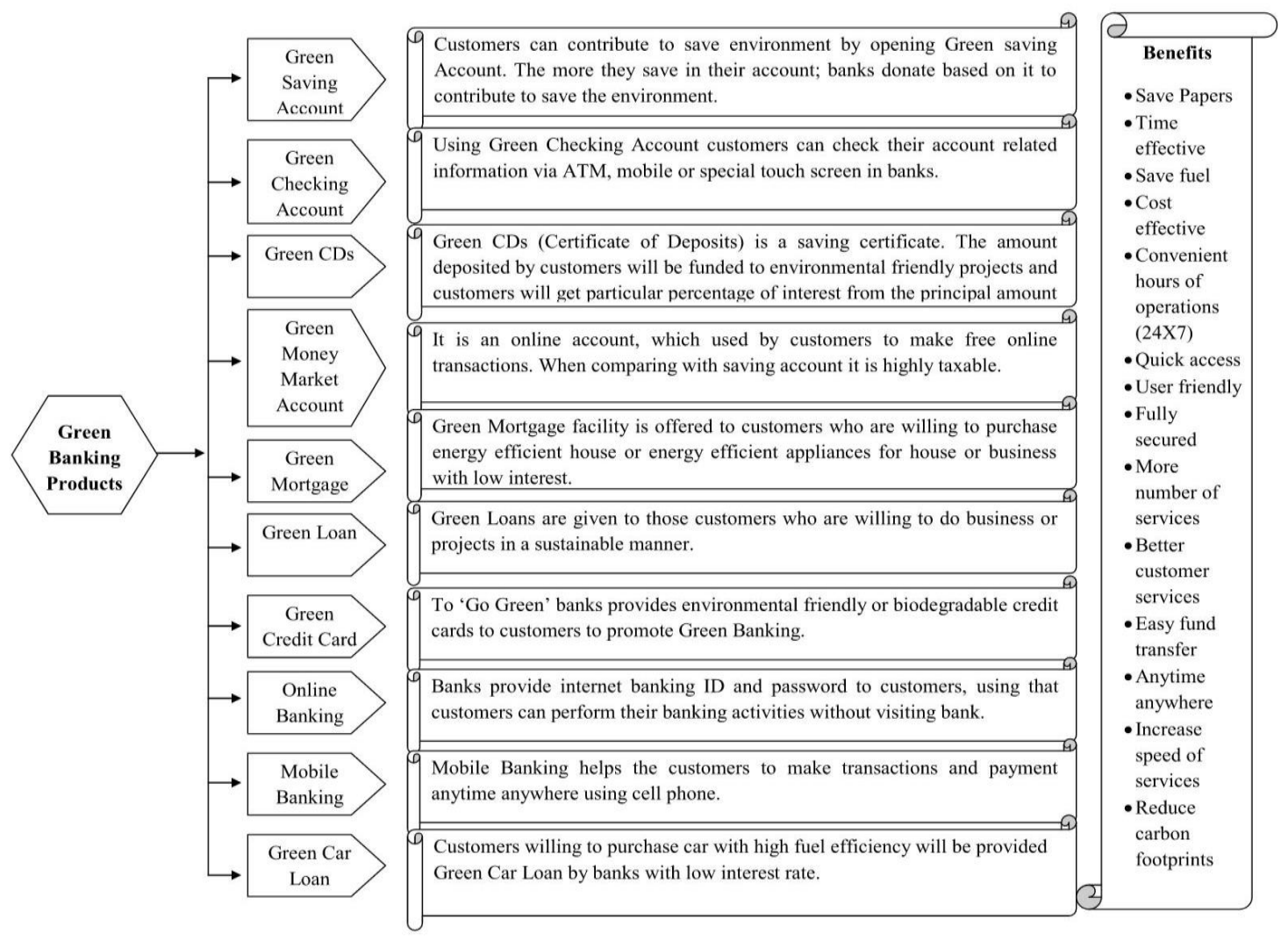

Figure 1:Green Banking Products (Source: Primary Data)

To promote the concept of Green Banking, banks took many initiatives one among them is Green Banking Products (Krishna, 2020). Green Banking Products are renewable, toxic-free, technologically designed to reach the goal of sustainability in banking to protect the planet for a greener future.

\section{Review of literature}

Sankareswari (2020) in her study "A comparative study on Green banking initiatives of SBI with $\mathrm{ICICI}$ bank - with special reference to Madurai city" examined the customers' awareness on Green Banking services offered by SBI and ICICI banks. It was found that $56 \%$ of SBI bank customers and $58 \%$ of $\mathrm{ICICl}$ bank customers were aware and using Green Banking services. Online banking and Mobile banking are highly used in Green Banking services. Other customers are not using Green Banking due to a lack of knowledge and security concerns.

Debnath and Roy (2019) in their study titled "Customer's awareness on Green Banking initiatives" highlights that banks should reduce the carbon footprints in their banking activities to protect the environment. Implementation of Green Banking products is not enough it should be properly utilized by customers. The study finds that banking customers havea lack of awareness about Green Banking; the banks should take necessary steps to educate their customers about Green Banking products.

Thomas and Linson (2018)in the study titled "Customers' awareness and adoption of Green Banking in Thrissur District" analyzed the awareness and adoption of Green Banking products among customers. It was found that $68 \%$ of respondents were Green Banking users, $88 \%$ of customers were aware of net banking and the majority $89 \%$ of customers does not have awareness about solar ATMs. The study suggests that the banks should take initiatives to create awareness among the customers about Green Banking products through the bank's website. 


\section{Objectives of the study}

1. To find out customers' awareness on Green Banking products.

2. Toassess the awareness about Green Banking products among male and female customers.

3. To ascertain the type of bank with Green Banking products awareness among customers.

\section{Research methodology}

The researcher has chosen a descriptive research design for this study, which aimed to look into the customers' awareness on Green Banking products. The primary data for this study is collected through a well-designed questionnaire from customers of public and private sector banks in Kanyakumari District, and secondary data gathered from journals. A simple random sampling technique is used in this study and the sample size was 160 . Percentage analysis and Independent sample t-Test are used to analysis the research data.

\section{Analysis and interpretation}

Table 1: Customer awareness on Green Banking Products

\begin{tabular}{|l|c|c|}
\hline $\begin{array}{l}\text { Awareness on Green } \\
\text { Banking Products }\end{array}$ & Frequency & Percentage \\
\hline Aware & 98 & 61.2 \\
\hline Not Aware & 62 & 38.8 \\
\hline Total & 160 & 100 \\
\hline
\end{tabular}

Source:Primary data

\section{Inference}

It is inferred from table 1, out of the 160 public and private sector bank customers, 98 (61.2\%) respondents were aware of Green Banking Products and 62 (38.8\%) respondents were not aware of Green Banking Products. It shows that majority of the respondents having awareness on Green Banking Products.

Table 2: Gender with respect to Awareness of Green Banking Products

\begin{tabular}{|c|c|c|c|c|c|c|}
\hline \multirow{3}{*}{ Green Banking Products } & \multicolumn{4}{|c|}{ Gender } & \multirow{3}{*}{$\mathrm{t}$ value } & \multirow{3}{*}{$P$ value } \\
\hline & \multicolumn{2}{|c|}{ Male } & \multicolumn{2}{|c|}{ Female } & & \\
\hline & Mean & SD & Mean & SD & & \\
\hline Green savings accounts & 3.89 & 1.316 & 3.73 & 1.253 & 0.807 & 0.421 \\
\hline Green checking accounts & 3.70 & 1.266 & 3.69 & 1.127 & 0.055 & 0.956 \\
\hline Green CDs & 3.36 & 1.205 & 3.31 & 1.161 & 0.265 & 0.791 \\
\hline $\begin{array}{l}\text { Green money market } \\
\text { accounts }\end{array}$ & 2.98 & 1.325 & 2.57 & 1.229 & 1.997 & $0.048^{*}$ \\
\hline Green mortgages & 3.01 & 1.184 & 2.57 & 1.163 & 2.378 & $0.019 *$ \\
\hline Green loans & 3.28 & 1.300 & 2.96 & 1.251 & 1.565 & 0.120 \\
\hline Green credit cards & 3.31 & 1.343 & 3.01 & 1.262 & 1.455 & 0.148 \\
\hline Mobile banking & 4.02 & 1.239 & 3.66 & 1.273 & 1.821 & 0.071 \\
\hline Online banking & 4.00 & 1.297 & 3.52 & 1.314 & 2.327 & $0.021 *$ \\
\hline Green car loans & 2.69 & 1.315 & 2.32 & 1.175 & 1.839 & 0.068 \\
\hline
\end{tabular}

$\mathrm{H}_{0}$ : There is no significant difference between Male and Female with Awareness of Green Banking Product. 


\section{Inference}

The significant difference exists between the respondents based on Gender and awareness of Green Banking products are compared by using t-test in table 2 .

Since the P-value is less than 0.05 , the null hypothesis is rejected at $5 \%$. Hence there is a significance difference between male and female bank customers with regard to awareness of Green Banking Products of Green Money Market Account, Green Mortgages, and Online Banking.

Since P-value is greater than 0.05 , the null hypothesis is accepted at $5 \%$ level. Hence there is no significance difference between male and female bank customers with regardto awareness of Green Banking Products of Green Savings Account, Green Checking Account, Green CD's, Green Loans, Green Credit Cards, Mobile Banking, and Green Car Loans.

Table 3: Type of Bank with respect to Awareness of Green Banking Products

\begin{tabular}{|c|c|c|c|c|c|c|}
\hline \multirow{3}{*}{ Green Banking Products } & \multicolumn{4}{|c|}{ Type of Bank } & \multirow{3}{*}{$\mathrm{t}$ value } & \multirow{3}{*}{ P value } \\
\hline & \multicolumn{2}{|c|}{ Public Sector Bank } & \multicolumn{2}{|c|}{$\begin{array}{c}\text { Private Sector } \\
\text { Bank }\end{array}$} & & \\
\hline & Mean & SD & Mean & SD & & \\
\hline Green savings accounts & 3.86 & 1.166 & 3.76 & 1.398 & 0.491 & 0.0624 \\
\hline Green checking accounts & 3.76 & 1.094 & 3.63 & 1.296 & 0.725 & 0.469 \\
\hline Green CDs & 3.40 & 0.936 & 3.28 & 1.387 & 0.668 & 0.505 \\
\hline $\begin{array}{l}\text { Green money market } \\
\text { accounts }\end{array}$ & 3.11 & 1.212 & 2.45 & 1.292 & 3.346 & $0.001 * *$ \\
\hline Green mortgages & 2.99 & 1.164 & 2.61 & 1.196 & 2.010 & $0.046^{*}$ \\
\hline Green loans & 3.19 & 1.181 & 3.06 & 1.381 & 0.615 & 0.539 \\
\hline Green credit cards & 3.25 & 1.196 & 3.09 & 1.416 & 0.784 & 0.434 \\
\hline Mobile banking & 3.96 & 1.216 & 3.74 & 1.310 & 1.126 & 0.264 \\
\hline Online banking & 3.98 & 1.211 & 3.56 & 1.404 & 1.990 & $0.048^{*}$ \\
\hline Green car loans & 2.69 & 1.239 & 2.34 & 1.262 & 1.770 & 0.079 \\
\hline
\end{tabular}

$\mathrm{H}_{0}$ : There is no significant difference between Type of Banks with Awareness of Green Banking Products

\section{Inference}

The significant difference exists between the respondents based on the type of bank and awareness of Green Banking products are compared by using t-test in table 3.

Since the P-value is less than 0.01 , the null hypothesis is rejected at $1 \%$. Hence there is a significance difference between public and private sector banks with regard to awareness of Green Banking Product of Green Money Market Account.

Since the P-value is less than 0.05 , the null hypothesis is rejected at $5 \%$. Hence there is a significance difference between public and private sector banks with regard to awareness of Green Banking Products of Green Mortgage and Online Banking.

Since P-value is greater than 0.05 , the null hypothesis is accepted at $5 \%$ level. Hence there is no significance difference between public and private sector banks with regardto awareness of Green Banking Products of Green Savings Account, Green Checking Account, Green CD's, Green Loans, Green Credit Cards, Mobile Banking, and Green Car Loans.

\section{Findings of the study}

$>$ From the study, it was found that $61.2 \%$ majority of respondents were aware of Green Banking Products offered by public and private sector banks in Kanyakumari District.

$>$ Independent sample t-Test reveals that there is a significance difference between male and female bank customers with regard to awareness of Green Banking Products of Green Money Market 
Account, Green Mortgages, and Online Banking.Based on the mean score, it was found that male bank customers are more aware of Green Banking Products than female bank customers.

$>$ From the Independent sample t-Test, it was found that there is a significance difference between public and private sector banks with regard to awareness of Green Banking Product of Green Money Market Account, Green Mortgage, and Online Banking. Based on the mean score, it was found that the public sector banks customers are more aware of Green Banking Products than private sector banks customers.

$>$ Online banking is the most aware Green Banking Product among the customers of public and private sector banks in the Kanyakumari District.

\section{Conclusion and recommendation}

People are running behind money for the advancement of the economy and society to improve their standard of living. However, they neglected to realize that, economy and environment are two different sides of the same coin; any sort of harm made by people in any one of the sidesfor their selfcenteredness may make the coin invaluable. When comparing the banking sector globally, Indian banking sectors are lagging in Green Banking initiatives and usage. From this study, it is clear that public and private sector banks customers have average awareness about Green Banking products. Implementation of Green Banking does not bring success and reduce the carbon impressions in banking activities, awareness about Green banking products and customers' habits of using ecofriendly practices are important for reaching the goal of sustainability. Customers of public and private sector banks in the Kanyakumari District are more aware of online banking, but they do not have much awareness about other Green Banking products. It's the responsibility of banks to create awareness about Green Banking products and make the customers start using Green Banking Products to protect the environment. A small step taken today by each customer will make a huge change tomorrow.

\section{References}

1. Debnath, S., \& Roy, S. (2019). Customer's awareness on green banking initiatives. Journal of Management, 7 (2), 75-78.

2. Deepa, P., \&Karpagam, D. C. (2018). A Study on Customer's Awareness on Green Banking in Selected Public and Private Sector Banks with Reference to Tirupur. International Journal of Advanced Research and Development, 3(1), 58-63.

3. Deka, G. (2018). Adoption and usage of sustainable green banking practices: An empirical study on internet banking in Assam. International Journal of Business and Management Invention (IJBMI), 7(8), 09-22.

4. Depika. (2015). Green Banking in India: A study of various strategies adopt by banks for sustainable development. In Bhatia, Setia\&Dheeraj (Eds.), National conference on emerging trends in engineering, management and science. (pp.198-206). Gujarat, India: International Journal of Engineering Research and Technology (IJERT).

5. Ganesan, R.,\&Bhuvaneswari, A. (2016). Customer perception towards green banking. Journal of Economics and Finance, 7 (5), 05-17. doi:10.9790/5933-0705010517

6. Giridhar, K. V.,\&Sudhakar, K. G. (2017). Green Banking: Issues and challenges in India. International Journal of Latest Technology in Engineering, Management and Applied Science, 6 (6), 130-132.

7. Krishna, D. V. (2020). A study on green banking system -our money, our world. MuktShabd Journal, 9(4), 26-31. doi:09.0014.MSJ.2020.V9I4(s).0086781.1904

8. Kumar, S. C. (2017). A study on customers awareness on Green Banking initiatives in selected private sector banks with reference to Kunnamkulam municipality. SSRG International Journal of Economics and Management Studies, 4 (3), 40-42. doi: 10.14445/23939125/IJEMS-V4I3P109

9. Malliga, AL. \&Revathy, K. (2016). Customer Awareness on Green Banking-An initiative by Private Sector Banks in Theni District. International Journal of Economic and Business Review, 4(5), 58-66. 
10.Nasila, N. (2020). Green banking products with special emphasis on Federal bank. MuktShabd Journal, 9(4), 432-436. doi:09.0014.MSJ.2020.V9I4(s).0086781.1968

11.Sankareswari, S. (2020). A comparative study on green banking initiatives of SBI with ICICI bankwith special reference to Madurai city. Alochana Chakra Journal, 9 (8), 2091-2099.

12.Thomas, J., \&Linson, S. (2018). Customers' awareness and adoption of Green Banking in Thrissur District. VISTAS A Multidisciplinary Research Journal, 7(1), 37-46. Retrieved from http://stjosephs.edu.in/upload/papers/7246f6c407ecb54e5af4c18fc8a9551e.pdf

13.Vijai, C. (2018). A Study on Customer's Awareness on Green Banking Initiatives in Selected Public and Private Sector Banks with Special Reference to Cuddalore District. International Journal of Innovative Research in Science, Engineering and Technology, 7(11), 9362-9367. 